\title{
Case selection in dental bleaching
}

\author{
Irina-Maria Gheorghiu', Paula Perlea', Sanziana Scarlatescu' ${ }^{2}$, George Nicola ${ }^{3}$ \\ ${ }^{1}$ Department of Restorative Odontotherapy, Faculty of Dental Medicine, \\ "Carol Davila" University of Medicine and Pharmacy, Bucharest \\ 2 Department of Endodontics, Faculty of Dental Medicine, "Carol Davila" University of Medicine and Pharmacy, Bucharest \\ ${ }^{3}$ Department of Medical Legal Elements and Malpractice, Faculty of Medicine, \\ "Carol Davila" University of Medicine and Pharmacy, Bucharest
}

\begin{abstract}
Dental bleaching is a method of treatment for tooth discoloration that uses hydrogen peroxide in various concentrations. For this dental maneuver to be successful, the etiological diagnosis of dental dyschromia and the treatment plan must be rigorously established. In this article we present the criteria underlying the selection of patients who can benefit from dental bleaching, grouped in a questionnaire. Adequate case selection suitable for teeth whitening, as well as the appropriate choice of the specific bleaching method are essential in obtaining satisfactory aesthetic result for the patient, immediately after completing the treatment, but also in the long term.
\end{abstract}

Keywords: tooth discoloration, case selection, dental bleaching

\section{INTRODUCTION}

Dental bleaching is the method of treatment of choice for the teeth that have undergone color changes( discoloration), in order to restore the initial shade. Often, this is a borderline procedure between a medical act, with an objective etiological basis and real medical indication - and a maneuver of improving the physical appearance. In this last situation, the tooth whitening procedure is more dental cosmetics, and its usefulness must always be established by the dentist [1].

When we are talking about dental bleaching from this point of view, the diagnosis and the treatment plan must be rigorously established. The most important is the adequate selection of patients who can receive tooth whitening. Following this, by choosing the optimal treatment method, a result can be obtained as close as possible to the patient's wishes and expectations. This also avoids any misunderstandings or dissatisfaction of patients, which could lead to a medical dispute, resulting in the legal liability of the dentist [2].
Dental bleaching methods address both vital and non-vital teeth. They can be performed in the dental office (in-office bleaching), or they can be performed by the patient at home (outside the office). The latter option is usually performed by the patient using over the counter whitening products, without the advice and consent of the dentist, and the results and effects may be inadequate.

Treatment of discoloured teeth is a chemical procedure that uses hydrogen peroxide in different concentrations. Basically the effect is changing the optical parameters of the dental structures whose color has been affected. Along with it are also used: carbamide peroxide, sodium perchlorate, sodium perborate [3,4].

\section{CASE SELECTION FOR DENTAL BLEACHING}

The following preliminary steps are absolutely mandatory in order to achieve in office bleaching, right from the moment the patient presents to the dental office, so a successful result from all points of view: 
- Determining the diagnosis of the etiology of tooth discoloration is the most important determinant of the success of any bleaching method.

- Establishing the status of the teeth and the entire oral cavity that determined the bleaching method which will be applied. For example, the presence of affected or compromised teeth may interfere with one of the bleaching treatment types, by limiting the use of a certain concentration of bleaching agent, or light activated methods [5].

In this regard, the anamnesis provides the essential data about the patient's medical history, as well as the eating and oral hygiene habits. The patient should be investigated for systemic conditions or medications that have induced discoloration of the dental structures. These discolorations can be generated by treatments / pathologies during the period of dental development, so the medical history must include this period as well [6]. Equally relevant and important are finding out the place of birth and the place (s) in which the patient lived in childhood and adolescence, knowing that water fluoridation levels may be different in different re- gions or there may be extrinsic toxins as well as others harmful environmental factors.

The patient's eating, drinking, parafunctions history is also essential, providing information on vicious habits that are maintained today and may interfere with the desired outcome.

The questions can be grouped in a special questionnaire specific to the dental bleaching treatment, attached to the current one used in dental office, by which the patient gives his consent for the medical act.

The patients' written answers, in association with the discussion with the dentist, are subsequently corroborated with the objective examination. Thus, a correct etiological diagnosis of tooth discoloration can be established. It is known that they can be: extrinsic (food, smoking) or intrinsic (due to febrile / infectious diseases, medication with antibiotics such as tetracycline during dental development, excessive fluoridation, or, in some cases, genetic pathologies) [7].

The objective clinical examination determines exactly the dental status, as well as the situation of the marginal periodontium, knowing it's importance in terms of dental aesthetics (gingival retrac-

TABLE 1. Questionnaire for dental bleaching

\begin{tabular}{|c|c|}
\hline Question & Patient's answer \\
\hline \multicolumn{2}{|l|}{ What is the reason for requesting a dental bleaching now? } \\
\hline \multicolumn{2}{|l|}{ Do you know what medications your mother took during pregnancy? } \\
\hline \multicolumn{2}{|l|}{ Were you born full term or prematurely? } \\
\hline \multicolumn{2}{|l|}{ What Rh do you have? Was there an incompatibility with the mother at birth? } \\
\hline \multicolumn{2}{|l|}{ Was the nutrition during childhood adequate? Were there periods of economic hardship? } \\
\hline \multicolumn{2}{|l|}{ Did you have infectious diseases as a child? If so, mention what they were } \\
\hline \multicolumn{2}{|l|}{ Did you receive antibiotic treatment as a child? If so, with what drugs? } \\
\hline \multicolumn{2}{|l|}{ Are there any genetic disorders in your family? Have you been diagnosed with any? } \\
\hline \multicolumn{2}{|l|}{ Have you received dental caries prevention treatments such as topical fluoridation? } \\
\hline \multicolumn{2}{|l|}{$\begin{array}{l}\text { Have you received preventive treatments with systemic fluoride? If so, in what period of } \\
\text { childhood? }\end{array}$} \\
\hline \multicolumn{2}{|l|}{ In what city / area were you born and lived? Mention the time periods. } \\
\hline \multicolumn{2}{|l|}{$\begin{array}{l}\text { Have you undergone dental treatments as a child? If yes, mention their type (dental fillings, } \\
\text { extractions, etc.) }\end{array}$} \\
\hline \multicolumn{2}{|l|}{ Did you suffer traumas in the cephalic area as a child? } \\
\hline \multicolumn{2}{|l|}{$\begin{array}{l}\text { What are the habits of daily oral hygiene? How many times do you brush your teeth? Do you use } \\
\text { chlorhexidine mouthwash? }\end{array}$} \\
\hline \multicolumn{2}{|l|}{$\begin{array}{l}\text { Have you had any previous dental bleaching treatments? If so, how many and what type? ( in } \\
\text { office bleaching, at home bleaching) }\end{array}$} \\
\hline \multicolumn{2}{|l|}{$\begin{array}{l}\text { Have you experienced side effects of previously performed dental bleaching (dental } \\
\text { hypersensitivity, fast color regression to the original shade, increased incidence of carious } \\
\text { processes)? }\end{array}$} \\
\hline \multicolumn{2}{|l|}{ Were you satisfied with the results of the previous dental bleaching methods? If not, why? } \\
\hline \multicolumn{2}{|l|}{ Do you have oral parafunction: bruxism, nail biting, lip or various objects biting? } \\
\hline \multicolumn{2}{|l|}{$\begin{array}{l}\text { What are your eating/drinking habits? What type of food do you mainly eat? } \\
\text { Tea, coffee, acid drinks? Soft or hard foods? }\end{array}$} \\
\hline \multicolumn{2}{|l|}{ Do you smoke? If so, since when and what is the number of cigarettes per day? } \\
\hline \multicolumn{2}{|l|}{$\begin{array}{l}\text { Are you willing to make changes to your lifestyle / diet to get and maintain an optimal dental } \\
\text { bleaching result? (smoking cessation) }\end{array}$} \\
\hline $\begin{array}{l}\text { Have you recently received orthodontic treatments or dental restorations? If so, is there a dental } \\
\text { hypersensitivity at this time? }\end{array}$ & \\
\hline
\end{tabular}


tions exposing the root surface covered by cement), as well as the increased risk of hypersensitivity and dentinal hyperesthesia at this level after dental bleaching [8].

Complementary examinations, of which radiography is the most important, provide relevant information on the following aspects: apical periodontal status, possible changes in endodontic space, the presence of non vital teeth (dyschromia following pulp vitality loss), correctness of previous endodontic treatments, the existence of associated pathologies that require immediate treatment.

Complementary examinations before any in office bleaching treatment should include pulp vitality tests, as well as fiber optic transillumination techniques. The latter reveal dental caries, enamel cracks, hypo / decalcification areas or areas of hypercalcification [9]. In this way, the bleaching technique that is optimal for the respective clinical situation can be chosen accordingly.

Extremely important is the visualization and especially the recording of data related to dental color with the help of intraoral cameras / photographs. The intraoral cameras offer detection and accurate representation of present dental status. They are useful both in the diagnostic phase, allowing the capture and display images from inside patient's mouth, and in the design of the treatment plan, allowing the virtual visualization by the patient of the possible tooth shades that can be obtained. Also, images may be needed during treatment in order to track the cumulative effect of treatment. Last but not least, imaging recordings can be a legal document when the patient is not satisfied with the results of the bleaching treatment $[10,11]$.

\section{REFERENCES}

1. Silva FBD, Chisini LA, Demarco FF, Horta BL, Correa MB. Desire for tooth bleaching and treatment performed in Brazilian adults: findings from a birth cohort. Braz Oral Res. 2018;32:e12.

2. Pituru S, Vladareanu S, Paun S, Nanu A. Malpractice and professional liability of medical personnel. Farmacia. 2015;63(2):318-324.

3. Gheorghiu IM, Mironiuc-Cureu M, Scarlatescu S, Iliescu G, Perlea P, Iliescu AA. Consideratii actuale privind metoda de albire a dintilor vitali in cabinet. Ro J Med Pract. 2014;9(4):230-233.

4. Lazarescu F. Incursiune în estetica dentară. SSER. 2013:200-210.

5. Alshammery S. Evaluation of Light Activation on In-office Dental Bleaching: A Systematic Review. J Contemp Dent Pract. 2019;20(11):1355-1360.

6. Gheorghiu IM, Mitran L, Mitran M, Suciu I, Mironiuc-Cureu M. In-office bleaching. ORL.ro. 2014;24(3):38-40.

7. Bloomquist RF, Sword RJ, Londono J, Haywood VB. Bleaching: the initial treatment consideration for tetracycline-stained teeth. $\mathrm{Br}$ Dent J. 2021;230(12):807-812.

8. Soares DG, Sacono NT, Ribeiro AP, Basso FG, Scheffel DS, Hebling J, Costa CA. Responses of dental pulp cells to a less invasive bleaching
Prior to any tooth whitening treatments, a prophylactic removal of bacterial dental plaque and dental calculus deposits must be performed, by dental scaling, associated with professional brushing. These lead to the real determination of the initial tooth shade. In some situations, this preparation may even cause the patient to be satisfied with the tooth color obtained after removing the extrinsic stains and he may give up for dental bleaching.

The patient's contribution in obtaining and maintaining the results is also important through: reasonable expectations and requirements regarding the final dental color, his desire for cooperation and patience during the treatment stages, availability to change inappropriate parafunction or eating/ drinking habits [12]. The patient must also be aware that in many clinical situations dental bleaching must be an integral part of a complete and complex interdisciplinary rehabilitation of the entire oral cavity [13].

\section{CONCLUSIONS}

Adequate case selection suitable for teeth whitening, as well as the appropriate choice of the specific bleaching method are essential in order to obtain a satisfactory aesthetic result for the patient, immediately after the completion of the treatment, but also in the long term.

\section{Acknowledgement}

All the authors have equal contributions for this article.

Conflict of interest: none declared Financial support: none declared

technique applied to adhesive-restored teeth. J Adhes Dent. 2015;17(2):155-61.

9. Heyman HO, Swift jr EJ, Ritter AV. Sturdevant's Art and Science of Operative Dentistry. 6th ed. Mosby Elsevier 2013:89-112.

10. Gheorghiu IM, Perlea P, Temelcea AN. Ethical issues related to dental bleaching. Rom J Leg Med. 2019;27:78-82.

11. Nicola G, Gheorghiu IM, Scarlatescu S, Constantinescu FE, Perlea P. Managing the relationship with the press in the context of medical malpractice accusation. J Leg Med. 2020;28:348-354.

12. Bersezio C, Martín J, Mayer C, Rivera O, Estay J, Vernal R, Haidar ZS, Angel P, Oliveira OB Jr, Fernández E. Quality of life and stability of tooth color change at three months after dental bleaching. Qual Life Res. 2018;27(12):3199-3207.

13. Espíndola-Castro LF, de Melo Monteiro GQ, Ortigoza LS, da Silva CHV, Souto-Maior JR. Multidisciplinary Approach to Smile Restoration: Gingivoplasty, Tooth Bleaching, and Dental Re-anatomization. Compend Contin Educ Dent. 2019 Oct;40(9):590-599. 